\title{
Educating the transnational network
}

\author{
Chiara Larghi
}

\section{Introduction}

'Education is the most powerful weapon which you can use to change the world.'

- Nelson Mandela

In the context of a broader and more specific discourse on private law, this paper turns its attention towards the big picture of the European project. The focus of the research is not particularly on the substantive or normative dimension of EU legislation, rather on the people behind its private law. The aim was to understand how legal education could impact the development of EU law. Therefore, the attempt has been that of, firstly, identifying the political dynamics which produce and sustain the law (section I) and, secondly, investigating the cultural dimension of the integration process, specifically on how nationalistic views tend to reject legal harmonization on cultural premises (section II).

From the political perspective, the analysis revolves around the notions of supranational constitutionalism and deliberative supranationalism. While the general tendency is that of considering private and public law as two very separate legal spheres, through the theory of supranational constitutionalism this paper explores the constitutional elements intertwined with the private law of the European Union. More specifically, as national constitutional models fail to perceive the presence of foreign EU citizens within their borders, a system of EU private law should be sustained in order to create a uniform and coherent corpus of laws in which general principles of private law and fundamental constitutional rights are guaranteed for all the market citizens moving and operating cross-border. In other words, with the purpose of including a wider social dimension within the Union's Economic Constitution, this study suggests the necessity of expanding the current realm of EU private law as to entail European ground rules and standards equally applicable throughout the whole Internal Market.

In order to ensure the legitimacy of such a comprehensive EU private law system, this author employs the doctrine of deliberative supranationalism. According to this approach, a legitimate integration process builds upon the premise that important and relevant 
political decisions must be taken upon well-informed and properly educated judgements of facts and opinions. This calls for the capacity of engaging in a multicultural and pluralistic legal discourse in which cultural differences are not perceived as hindrance to further integration, rather as a source of confrontation and improvement.

While researching in the political and cultural areas, one of the most recurrent words was 'network'. The political-legal actors, fulcrum of this analysis, are in fact organized in networks: as any other social individual, they are part of a web of relations and connections which expands throughout the whole Union, across the territorial confines. From this came the notion transnational network. Similarly, other theories suggested that culture can no longer be perceived as homogeneous and fixed: culture is multifaceted, pluralistic and cannot be limited within national boundaries.

If the politics and the cultures of Europe are set in networks and if these networks are international and pluralistic, then legal education should be organized accordingly. Starting from the belief that it is through education that we may create a more conscious transnational network, and thus enhance the legal harmonization process, the claim is that an innovative EU law scholarship should be created. This new EU law curriculum would be independent from any other traditional legal school, it would be aimed at shaping a professional and academic identity that is capable of working with any source of law, whether national or international. Such school would concentrate on the formation of future practitioners able of coping with a global world in which law is no longer a national phenomenon and in which legal problems are often cross-border issues. For this reason, the EU law school should strive for an international outlook and adopt practical approaches through which students are trained on how to create an intellectual link with the every-day practice and with the political mechanisms existing within the Union. 


\section{Legal Europeanisation and its politics: The art of the possible}

"Laws, like sausages, cease to inspire respect in proportion as we know how they are made", said Mr. John Godfrey Saxe more than a century ago.' What the poet referred to was, indeed, the amount of political bargaining and compromise that precedes any given law. The same holds true with regards to any kind of EU legislation. It is not only with respect to treaty law, but also regulations, directives, recommendations: the longer their preamble, the more political is the document.

However technical a specific provision may seem, it is never simply the result of apolitical cooperation between a group of legal and scientific experts, rather the best deal agreed by different constituencies whose economic and social interests were squeezed together into one final rule. Without intending to advance any criticism as to the level and quality of lobbyism present in Brussels, nor the apparent predominance of economic and market driven regulation created by the Union, this section attempts to analyse the process of political integration which may explain the legitimacy of the Europeanisation of private law.

The legal academic debate surrounding the development of EU law generally focuses on the substantial content of passed, proposed or failed legislation, while the author's intention is that of better understanding the political mechanisms standing behind the promotion of- or the scepticism towards- legal integration and, more importantly, the actors steering the wheel in one or the other direction. As soon as the debate touches upon the feasibility of further legal integration, the contrast between those in favour and those against a EU private law system becomes fierce. On the one hand the Europeanists who, following the arguments advanced by Zimmermann, believe in the (future) possibility of a European Civil Code. ${ }^{2}$ On the other hand, the Nationalists who advocate that Brussels should not interfere with the Member States' private law systems as, expressed in Legrandian terms, the legal mentalités of the countries can never be reconciled. ${ }^{3}$

1 A more famous version of the quote ('Laws are like sausages. It is better not to see them being made') is generally attributed to Prince Otto van Bismarck, but from The Chronicle of University of Michigan (29 March 1869) the quote was reported as been mentioned by an American poet, Mr. John Godfrey Saxe.

2 Lando 1997, p. 525-536; Zimmermann 2009, p. 479-512.

3 Legrand 1997, p. 44-63. 
As a matter of fact, despite the highly interventionist attitude of the Union in regulating the Internal Market, most of the private law of the Member States has remained untouched, cherished in the hands of the nations which, internally, perceive their system as a permanent set of adjudicatory principles and rules with almost no ideological sentiment attached to it, but as soon as taken on an international plane, it becomes the symbol of the State's sovereignty, a system soaked with ideological and historical significance. ${ }^{4}$

Interestingly, while there might have been reluctance towards extensive legislative intervention in the core areas of private law, an impact of (negative and positive) integration- realized in pursuit of the four freedoms- on the structures of the national systems cannot be denied. By simply looking at the CJEU's case-law, we notice the establishment of 'general principles's of private law such as the freedom of contract, ${ }^{6}$ the new principle of non-withdrawal once all obligations have been performed, the principles of good faith and unjust enrichment ${ }^{8}$. Clearly, these principles still maintain a construct which is strictly related to those designed in the nation-state models, in the sense that they stem from doctrines and rules already established and accepted at the national levels. ${ }^{9}$ On the other hand, however, their acknowledgement by the Court as "European principles" indicates an impact of the economic integration on the national systems- in terms of reshaping concepts such as private autonomy and private actors' social responsibility- aimed at creating European standards, thus removing obstacles to trade created by the differing national approaches..$^{10}$

\subsection{Supranational constitutionalism in European private law}

In order to better assess the extent to which this area of law has been affected by European integration, Joerges suggests that an analysis of the constitutional dimensions of the process should be carried out. Borrowing the concept of "European economic constitution", it is claimed that EU law created a framework which cannot be intended as

4 Caruso 1997, p. 3-32.

5 Mak 2012, p. 5.

6 Case C-277/05, Société thermale d'Eugénie les Bains v Ministre de l'économie, des Finances et de I'Industrie [2007] ECR I-06415.

7 Case C-412/o6, Annelore Hamilton v Volksbank Filder [2008] ECR I-2383.

8 Case C-489/07 Messner v Firma Stefan Krüger [2009] ECR I-7315.

9 Mak 2012, p. 5.

10 Joerges 1997, p. 378-406. 
only protecting the economic rights and activities granted by the four market freedoms, but also as having supremacy over the nation-states' law within and outside which the (market) citizens should be able to exercise their constitutional (and politically guaranteed) rights." This perception of the Treaties as economic constitutions is what requires the economic market integration to be accompanied by the protection of constitutional and fundamental rights. In better words, the Union 'through its interpretation as an order constituted by law and committed to economic freedoms, acquires a legitimacy that protected it against all attacks motivated by democracy theory or constitutional policy.'.2

Through the adoption of an 'external value-based perspective' on EU private law, the subsequent stage would be that of employing the national constitutional models and fundamental rights as a starting point for the design of a European model which protects private law values and principles, a process which would occur both through judiciary and political deliberations of what EU private law should entail. ${ }^{13}$ This would depart from the notion of nation-centred politics: the European polity would, then, no longer be related to a unitary concept of statehood, rather it would comprise a plurality of national political units, and it would exist despite of the absence of a single unitary community to support its body of law. ${ }^{14}$

The objections raised against this constitutional approach on the validity of EU private law generate from the fear of national legal disintegration. Among the German scholars, there is concern that approximation would disintegrate the coherent internal legal systems, while on the other side of the Channel the biggest hurdle is constituted by the perceived impossibility of adapting a EU order to their legal traditions. ${ }^{15} \mathrm{If}$, however, the crucial role of constitutional and fundamental rights is finally taken into account, then, as no other ultimate source of law is yet in place, we may accept the development of 'general European principles' whose purpose is that of protecting the citizens of the market on a transnational level. ${ }^{16}$

\footnotetext{
11 Joerges 1997, p. 382.

12 lbid.

13 Mak 2012, p. 6.

14 Mak 2012, p. 4.

15 Joerges 1997, p. 385.

16 Mak 2012, p. 7; Study Group on Social Justice in European Private Law 2004, p. 653-674.
} 
With regards to the feasibility of a Civil Code for Europe- the emblem of EU private lawLegrand advocates the impossible reconcilability of the common law with the civil law tradition, defining it as an 'irrecusable (and irreducible) epistemological chasm' that 'has been wanted' through an attitude of refusal and rejection expressed by the lawyers who preceded us. ${ }^{17}$ Arguably, however, as this chasm was sought for, it may as well be worked around, provided the political willingness is there. The every-day practice demonstrates that, even if there is no common rationale from which the Commission may depart at the drafting phase (or at the working parties' level in the Council), the drafters (or the States' representatives) are perfectly capable of reaching common standing on meaningful elements: intercultural discourse is possible, the real question is whether it is wanted. ${ }^{18}$

The assumption that the common and the civil law traditions need necessarily to converge is a misleading one as it presupposes that to one legal order only one specific society and culture must correspond, but 'what if we can no longer reckon with this type of homogeneous background life-world, but instead with a fragmentation or pluralisation of cultures within our legally unitary societies?'. ${ }^{9}$ From the foregoing analysis on supranational constitutionalism it can be inferred that it is upon ground principles of constitutional nature that Europe, however internally diversified it may be, should begin to construct its private law system.

\subsection{The cult of the individual and the necessary shift to a network solidarity}

The above discussion culminates with the claim that integration requires a profound change in the structures of solidarity, legal order and justice in the form of a shift from the nation-based social dimension towards a European one. ${ }^{20}$ By relying on Münch's application of Durkheim's social theory, ${ }^{21}$ the author attempts to explain how the economic and social integration initiated by the market freedoms, has the potential of triggering deeper legal harmonization in the area of private law.

17 Legrand 1997, p. 46.

18 Joerges 1997, p. 386.

19 lbid.

20 Münch 2008, p. 519-541.

21

Durkheim's theory as applied by Münch in his analysis was integrated with the Barnes 1966, p. 158-175. 
In his The Division of Labour in Society, ${ }^{22}$ Durkheim identifies the engine of cross-border social integration in the respective cross-border division of labour. The transition from a nation-confined labour division to a new transnational one demands a departure from the traditional comfort zone and security found in the national tradition towards the insecurity of a new concept of European solidarity. ${ }^{23}$ This is what he defines as the shift from the mechanical solidarity present inside the national collective societies to the organic (or network) solidarity of a European society. Out in the real world, the risk of eroding or disregarding national traditions does not affect people's will to engage in cross-border labour division. ${ }^{24}$ Applied to the Union of today: the four freedoms allow the market citizens to increase specialization and get involved in cross-border activities. The more industrialisation (intended as e.g., population growth, improved means of transportation and communication) advances, the more distances between the peoples are reduced. This element of proximity was created inside the Union due to the market freedoms granted in the Treaties.

The consequential release from the national environment, in turn, permits freedom from national constraints, hence causing the loss of internal homogeneity that national collective consciences ${ }^{25}$ used to possess: societies get closer, nations begin to assimilate each other and differences between national cultures may finally fade. ${ }^{26}$ In a Europe with little international contacts, people remain confined within their native region where a uniform and homogenous collectivism exists and is protected by a form of repressive legal order, a concept which will be elaborated below. In the advanced Union, on the other hand, where transnational division of labour and specialization exist, there is a high level of interdependency and collectivism is replaced by individualism. ${ }^{27}$

To be more precise, the concept of mechanical solidarity referred above indicates the moral phenomenon which 'binds the individual directly to society without any intermediary', typical of collective-type societies where people share a common set of

\footnotetext{
22 Durkheim 1893.

23 Münch 2008, p. 520.

24 Ibid.

25 An expression borrowed from Durkheim's work- see: Wacks 2006; and: Barnes 1966, p. 164-165.

26 Micklitz 2010, p. 109-140.

27 Wacks 2006, p. 76.
} 
moral values simply because they belong to that specific society ${ }^{28}$ organic solidarity, on the other hand, refers to the moral phenomenon which arises when labour is divided among the members of society and in which such members become interdependent as they all contribute somehow to each other's life ${ }^{29}$. The passage from the former to the latter kind of solidarity is what, in the author's view, characterises the Union's legal arena. A transnational solidarity is created by elites of managers, scientists, politicians, lawyers, civil servants who carry out their activities on the international stage while depending on each other. ${ }^{30}$ This group of people push for the supranationalisation of solidarity and justice, causing a conflict with those constituencies whose interests and tendencies are still tied to national collective traditions. ${ }^{31}$ In other words, it is not so much a matter of spill-over, rather of clashing transnational and national impulses.

This change of solidarity is (or at least, should be) followed by a shift from a repressive system of law to a restitutive one, ${ }^{32}$ where the rights of the individuals are the main focus. It is the 'cult of the individual' which is to be reflected in a move from the national laws, in which collective interests and equality of results are protected (repressive), to a European law whose cardinal functional should be that of promoting the citizen's right, whether constitutional, fundamental, or civil (restitutive). EU law, then, becomes the result of legal practitioners' activity, aimed at protecting the autonomous individual operating on the Internal Market: as it develops within and in connection to the market, it is a law which must expand from economic to other areas of law.33

Following this rationale, the need for a EU private law system becomes more apparent. The creation of a single market calls for a distortion of the national orders. It demands the insertion of individual fundamental freedoms and the broadening of the realm of private law in terms of new responsibilities for the traders vis-à-vis the consumer. Steaming from the well known notion of information and bargain power asymmetries, EU regulation seeks to make up for such disparities. ${ }^{34}$ Nationalist resistance, based upon the

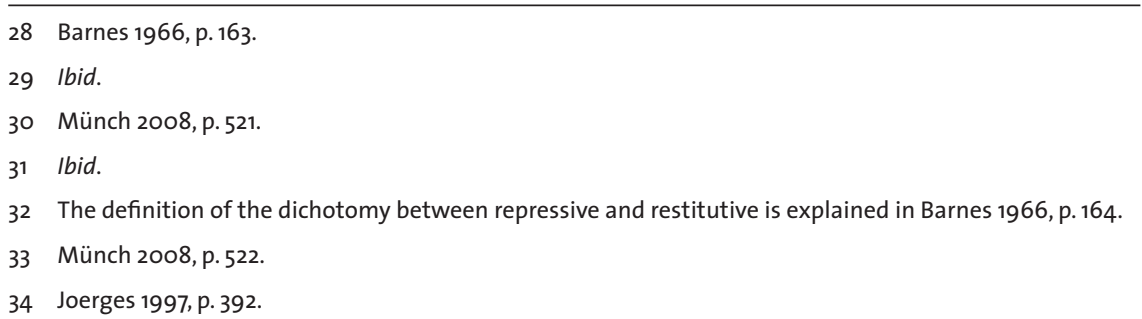


traditional nation-centred polity, cannot be overcome through the creation of a politically unified Euro-nation -simply because Europe is not ready yet and it might never be. This resistance, however, may be circumvented by accepting a weaker link between nation and polity, hence creating room for a supranational Euro-zone in which a multitude of political communities can co-exist and where solidarity- intended as a balance between the business and the consumer's interests ${ }^{35}$ - is strengthened and private law developed. ${ }^{36}$

\subsection{Deliberative supranationalism as a cure to the national constitutional lacunas}

Useful for this analysis is the connection between the Union's supranational character and the concept of deliberation. By adopting a (functional) deliberative approach, political integration is based on the premise that significant political decisions must be taken upon reflected and informed judgments of facts and opinions in a collective dialogue during which all participants interact, communicate and listen to each other: integration and problem-solving become a matter of 'open exchanges among informed parties'.37

From a strictly functional perspective, deliberation at the political level is what fosters efficient and normatively legitimate governance within the EU: supranationalism is the crucial characteristic which keeps the Union together despite the considerable 'diversity of interests and its lack of both coercive central enforcement authority and a functional equivalent to a national ideology'. ${ }^{8}$ As a common definition of what is 'just' cannot be detected, convergent beliefs and principles are not easy to find, but through deliberative processes of political integration, higher effectiveness and quality of EU decisionmaking are better ensured. As argued by Neyer, '(i)f the preferences of governments are only influenced by domestic concerns without being accommodated by supranational deliberations, negotiations often break down or deteriorate into "bloody-minded" bargaining'. ${ }^{39}$

From a constitutional perspective, the nation-state's model is introspective and exclusionary in the sense that the democratic discourse at its base represents the

\footnotetext{
35 Lurger 2011, p. 364-365.

36 Mak 2012, p. 12.

37 Joerges \& Neyer 2006, p. 2-3.

38 Joerges \& Neyer 2006, p. 8.

39 Joerges \& Neyer 2006, p. 9.
} 
collective national identity without any consideration of foreign presences (let alone of their interests). The national model's lacunas or vacuums can be filled by the creation of a European comprehensive system of private law which embraces fundamental constitutional rights and which guarantees their respect for all citizens, regardless of whether they operate within their native territory or abroad. The need for the recognition of such constitutional dimension in EU private law is advocated by Joerges and Neyer, whose analysis departs from the application of deliberative supranationalism to the political integration and ends with the legitimacy of supranational constitutionalism in EU law as a cure to the nation-shortcomings, ${ }^{\circ}$ and similarly by Mak, whose studies focus on the same constitutional aspects highlighted so far. ${ }^{41}$ According to the latter, in fact, traditional constitutional systems fail to entail concepts such as 'supranational citizenship' or 'co-existence of autonomous political communities' as much as traditional contract laws are not capable of recognizing the tension between market economic integration and consumer protection. ${ }^{42}$ This new EU constitutional order, in which the four market freedoms assume the features of fundamental rights ${ }^{43}$ calls for an adequate comprehensive system of private law or, perhaps less demandingly, of patrimonial law capable of embracing these new supranational constitutional principles.

Without necessarily suggesting the adoption of a European Code of substantive and procedural private law, the claim is that a more comprehensive legislative action should be undertaken, at least in the area of patrimonial law (i.e., law of contract, tort, unjust enrichment, and property). ${ }^{44}$ By engaging in an 'intellectually revolutionary process', a uniform legislation designed upon pure European considerations may be brought forward. 45 The cultural implications related to such an argument will be analyzed more in detail in the following section, for now it is simply stated that EU rules of private/ patrimonial law should be developed through a proper deliberative discourse at the political level. Moreover, these rules should be unvested of any national mentality and

40 This interpretation of deliberative supranationalism united to supranational constitutionalism is drawn from two different papers, namely: Joerges 1997, p. 378-406; Joerges \& Neyer 2006.

41 The author refers to two different articles, namely: Mak 2011, p. 333-352; Mak 2012.

42 Mak 2011, p. 333-334.

43 Mak 2011, p. 338.

44 The argument is presented in: van Gerven 2001. The concept of "patrimonial" law was, however, intended not to cover property law, rather 'the law of fiduciary relations' (see p. 11 of the text). 
rationale: the transplant of policy decisions and values from the national to the European level will not suffice for the simple reason that national (constitutional) models cannot reflect the supranational nature of the Union.

Borrowing the notion of 'multi-level governance' from the political sciences, ${ }^{46}$ it is possible to better grasp the validity of what asserted so far. By perceiving the Union as a system of multilevel governance, we may come to accept the erosion of closed, introspective nation-states, but at the same time we may also refuse the transformation of the EU into a super-state. ${ }^{47}$ In a way, the Union stands somewhere between a federal state and a mere international organization. The arena described until now is characterized by a constant friction between, from one side, the EU's welfarist aspiration and, on the other, the Member States' different perceptions of which social policies should be adopted. In other words, it is a system of governance in which the social market economy rationale needs to be balanced against national political, social and cultural aspects of private law. ${ }^{48}$ In this sui generis entity, economic and social affairs are managed by supranational institutions as well as by non-governmental actors whose deliberative political actions are organized in networks. ${ }^{49}$ Through the law-making and law-application procedures carried out by supranational institutions and individual actors, a 'transnational network',50 made of lawyers, judges, academics and public officials, found its way into the political and legal sphere of the Union.

Given that the activity of this elite of professionals is the engine of the conflict between national disintegration and cross-border integration (i.e., in Durkheim's terms, the necessary precondition of private law integration), it is argued that the efficiency of such an activity depends on the degree and on the quality of the communication and interaction between these autonomous, but yet interdependent, actors. The more properly informed, trained and coordinated this network is, the more deliberative political integration will be. In turn, the more deliberative and supranational the integration will be, the more it is likely that they will be able to develop a private law order in true European perspective capable of filling the vacuums left by the national systems, hence better equipped to guarantee an integral rights protection for all market citizens.

46 Concept defined, for example, by Amato 2008.

47 Joerges \& Neyer 2006, p. 27.

48 Reich 2011, p. 79.

49 Jeorges 1997, p. 387; Joerges\&Neyer 2006, p. 27.

50 Notion presented by Micklitz 2010, p. 126-127 and borrowed by Münch 2008. 
In order to create a competent transnational network, the author advocates the need for a European scholarship: only through the proper education of the future members of the network and the proper training of those already involved, the meeting of their minds will be achieved, thus increasing the chances necessary for the development and correct application of EU private law. ${ }^{51}$ Before discussing which elements the new academic curricula should entail (section III), a brief critical analysis of the nationalist approach towards culture in Europe will be carried out (section II).

\section{Extinguishing the Eisenach fire in the European legal Tower of Babel52}

Based on what presented previously, it is sustained that the nation-state is gradually mutating into a "citizen-state",53 intended as 'a state of citizens and inhabitants that are equal no matter where they come from' and who 'deserve the protection of the law, regardless of whether they are national of the country they reside or not'.54 National constitutions, alone, do no suffice to guarantee such protection due to the national vacuums explained in the previous section. Yet, as of today, Europe still lacks a comprehensive legal order: the legislator has been limited to specific- economic- issues and has legislated in a fragmented way. ${ }^{55}$

One of the most recurrent arguments advanced against a too intrusive Union has been the cultural argument, namely that the process of private law integration is not feasible as this would disrespect the cultural differences existing between the Member Statesdifferences which must be preserved as prescribed by Article 3 (IV) of the Treaty on the European Union, whereas others go even further by considering such a process practically

51 Van Gerven 2001, p. 27-28.

52 The 'Eisenach fire' expression refers to an episode occurred in 1817 in Eisenach (a German city). On that occasion the three-hundredth anniversary of the Lutheran reform was being celebrated and books of foreign authors were burned. Amongst the destroyed books stood a copy of the French Civil Code. The anecdote is emblematic of the nationalist attempts to homogenise societies during the past two centuries. Source of the information is found in: Comparato 2012, p. 245- 259, p. 246.

53 Term employed by Smits (see below 53) on p. 7, but referred to van Gerven \& Lierman's contribution,p. 41 ff.

54 Smits 2012, p.7.

55 Lopez-Rodriguez 2004, p. 1195-1220, p. 1198. 
not possible due to irreconcilable mentalités dictated by diverse cultural backgrounds. ${ }^{56}$ However, one immediate question comes to mind: where were these "cultural walls" between the Founding Member States when they sat together and created the European Coal and Steel Community in 1950? It appears that this romantic attachment to national identities and traditions became of relevance only recently as a response to the Union's attempt to harmonize in the area of private law- especially after the proposal for a European Civil Code, while in previous stages culture did not seem to (pre)occupy the academic and political minds so much. ${ }^{57}$

Another concern is the vagueness and ubiquity of this concept. A common definition of 'culture' or 'legal culture' does not exist, they are subject of anthropological, sociological, historical, political, legal studies but none of them can provide a complete definition of what they exactly entail and in what they exactly differ from each other. To a certain extent, the concept of legal culture has been employed in order to explain features of law and society for which another justification could not be found, as if culture represented the variable into a explanatory equation. ${ }^{58}$ Bierbrauer writes that law and legal systems are the products of culture, they 'form a structure of meaning that guides and organizes individuals and groups in everyday interactions and conflict situations', their 'structure is passed on through socially transmitted norms of conduct and rules of decisions that influence the construction of intentional systems, including cognitive processes and individual dispositions' with the latter manifesting themselves 'as attitudes, values, beliefs, and expectations'.59 Cotterrell states that culture nor legal culture can be seen as a unity, rather as the fusion of (i) values and beliefs, (ii) traditions and customs, (iii) emotional attachments and rejections (subjective feelings and perceptions), (iv) material elements, such as levels of technological development and economic integration (instrumental social relations). ${ }^{60}$

Many deploy 'culture' and 'tradition' interchangeably but, even if intertwined, they actually do not coincide. Husa ${ }^{61}$ carried out a study aimed at capturing the different epistemologies

\footnotetext{
56 Legrand 1997.

57 Hesselink 2012, p. 3.

58 Gibson \&. Caldeira 1996, p. 56; Husa 2012, p. 5.

59 Bierbrauer 1994, p. 243-264, p. 243.

60 Cotterrell 2008,p. 23-36.

61 Husa 2012.
} 
of legal culture and legal tradition, coming to define the former as 'external attitudes, ideas and expectations concerning law'62 and, by quoting Varga's work, as

'operative and creative contribution, through social activity rooted in underlying social culture, to express how people experience legal phenomenon, conceived as a kind of objectified potentiality, how and into what they form it through their cooperation, how and in what way they conceptualise it, and in what spirit, frame and purpose they make it the subject of theoretical representation and operation'.63

Legal culture, therefore, includes ethical values, legal doctrines and scholarships, judicial habits and skills, the logical thinking of practitioners, as well as their ideologies and professional rules of conducts. These are related to local history and custom- the latter intended as the basis of law. ${ }^{64}$ Legal tradition, instead, is 'the presence of the past'.65 Glenn indicates it as 'a loose conglomeration of data, organized around a basic theme or themes, and variously described as [...] a "language", a "playground". 66 It is a sort of gene or information transmitted from past to future generations and strengthened by exchanges and interactions with other external traditions. ${ }^{67}$

\subsection{Nationalism and legal culture}

Nationalist views tend to worry about the implications that the denationalisation of private law could have on the cultural identities of the Member States. For the sake of clarification, nationalism is the political theory according to which the territorial boundaries of a nation-state should coincide with one political unit only. ${ }^{68}$ Transposed onto the legal integration commenced with globalisation, nationalists began to insist on the principle that the territorial application of private law must correspond with the border of the state which created such law. ${ }^{69}$ Under this approach, culture is an efficient tool used to explain why nations should organize their political and legal institutions autonomously:

\footnotetext{
62 Husa 2012, p. 6 in reference to Cotterrell 2003, p. 150-151.

63 Varga 2005, p. 177-197, p. 182.

64 Durkheim's Division of Labour in Society, G. Simpson The Free Press (1947), p. 65.

65 Husa 2012, p. 12.

66 Glenn 2004, p. 15.

67 Husa 2012, p. 13.

68 Gellner 2006, p. 1.

69 Hesselink 2012, p. 4.
} 
each nationality has one people, one language, one culture- and its own law..$^{70}$ As written by Collins, each one of us posses a specific identity which was mainly shaped by the social environment in which we grew up, we live inside a specific community (e.g., a family, a group) and this forges our own personality: 'we cannot conceive of an individual separated from his or her community, its practices, culture and values'.71 From this perspective, private law is perceived as a social phenomenon whose form is dictated by the cultural identity of a given nation, thus by imposing on such nation a different legal order, we would create a completely different society altogether.

The tension between the intention of developing a 'closer union among the peoples of Europe'72 through efficient approximation of private law and the preservation of cultural diversity seems, according to nationalist rationales, insurmountable. Private law, intended as Collins suggests, is intrinsically and inextricably connected to the moral values and economic institutional arrangements of one country: harmonization brought by an external entity endangers the stability of 'the social basis from which individuals can establish and conserve meaning for their lives'.73 Following this line of reasoning, nationalists not only believe that private law is rooted into the cultural values, but also that its law is directly linked to the principle of distributive justice accepted by the citizens of that community: each society has its own understanding of what is 'just' and what is 'unfair', of how wealth should be redistributed on the markets, and therefore the only persons in the legitimate position to legislate are those whose identity was crafted upon the values of that specific community. ${ }^{74}$ Perceptions of what the European Union seeks to achieve may differ among the Member States, 75 hence a common legal system of private law- imposed by a non-national institution- is seen as not feasible.

While the author may accept the argument that a European private law system cannot be created without colliding with the legal identities of the Member States, this fundamental value attributed to 'law and culture' is rejected. The whole idea that we cannot manage to work under a common set of rules of private law because we have different cultures and

\footnotetext{
70 Comparato 2012, p. 252.

71 Collins 1995, p. 353-365, p. 357 in reference to: Sandel 1982.

72 Treaty on the Functioning of the European Union, Preamble par. 1.

73 Collins 1995, p. 363.

74 Comparato 2012, p. 251.

75 Collins 1995, p. 364.
} 
traditions is simply overrated. The fact that legal practitioners' minds may function slightly differently in each Member State is because they have been trained by different universities, they have practiced the law in different ways, their deontology and ideology differ, and also their personal experiences and expectations may be diverse. Those placed among nationalistic lines have yet to explain how all these differences- focused on national realitiesconstitute a normative reason for rejecting legal approximation at the European level..$^{76}$

This "nationalist bias" is especially evident in the analytical methods employed: most of the studies carried on legal mentalités- and their impacts on the institutions- are based on national empirical data and surveys ${ }^{77}$ which assume, rather than demonstrate, national divergences. Lost in 'confusion between descriptions, explanations, and confirmation biases', the danger is that of remaining stuck into circular argumentations: does the highly systematized German Civil Code come before the German mental propensity towards systematization or vice versa? ${ }^{78}$ How come differences amongst the States are so easily explained with reference to national cultures and not to their specific institutional settings?

As already suggested in section (I), today's societies are better described in terms of fragmentation and pluralisation than in terms of homogeneity and national territorial boundaries. If we accept the plurality and collectivity of cultural identities across and within national borders, then the Europeanist approach towards governance and politics of recognition presented in the previous section is further strengthened.79 If we accept that cultures differ and cannot be confined to territorial borders, then it can no longer be explained by conservative/nationalistic theories why national laws would be more suitable to respond to individuals' needs than supranational regulations. To sustain that, for instance, the Spanish rules on third party protection reflect the interests of Spanish citizens better than an hypothetic EU rule is an argument based on nationality rather than on the real economic role of all EU citizens (including the Spanish ones) of the Single Market.

76 Hesselink 2012, p. 2-3.

77 On, for instance, number and length of litigations, structure of legal institutions, respect for the law, attitude towards rules. See, as example, J. Gibson \& G. Caldeira 1996 (supra 57).

78 Comparato 2012, p. 256-257; Hesselink 2012, p. 3.

79 Comparato 2012, p. 256. 
In an Union made of 'networks of community [...] transnational regulation serves social networks that extend beyond the boundaries of nation states'.80 In a world of global interactions, a given social group comes across several other communities: this reinforces certain elements of our traditions and, in turn, we feel justified in rejecting any newdifferent- perspective.$^{81}$ At the same time, multiculturalism is perceived as a positive result of such interactions and a basically inevitable aspect of an international market on which people are allowed to move freely. Law, therefore, should promote transnational cultural discourse, while protecting 'ultimate values of respect for individual autonomy and dignity that encourage and protect social interaction and participation by all individuals in the national political society'. ${ }^{82}$ Referring back to Durkheim's work, moral individualism, i.e., the universal and intrinsic respect for other individuals as human beings, ${ }^{83}$ remains the starting point upon which any EU private law system should be developed, a system in which network solidarity and transnational cultures are promoted.

\subsection{The European legal culture}

Some scholars have gone even a step further, claiming not simply that national cultures are no longer homogeneous, but that a European legal culture as such already exists ${ }^{84}$ or, as Zimmermann would sustain, it 'did once exist'\$5. Based upon a study of the historical eras of Europe, Wiecker identifies three mean features of our legal culture, namely personalism, legalism, and intellectualism. ${ }^{86}$ European legal culture is personalistic in the sense that it is pervaded by the primacy of the individual as 'subject, end and intellectual point of reference in the idea of law ${ }^{37}$ which, in his view, is rooted in the Western tendency of perceiving human relations as "vis-à-vis the other person" rather than "together with the other person". ${ }^{88}$ This translated in a conception of law as a network of interpersonal relationships in which self-determination/assertion and solidarity/responsibility towards

\footnotetext{
80 Cotterrell 2008, p. 23.

81 Husa 2012, p. 12; Cotterrell 2008, p. 32.

82 Cotterrell 2008, p. 32.

83 lbid.

84 Hesselink 2002.

85 Zimmermann 1996, p.576-605, p. 600.

86 Wieacker 1990, p. 1-29, p. 19-20.

87 Wiaecker 1990, p. 20.

88 A tendency which, according to Wieacker's study, was inherited from the Ancient Greek polis and in the associated communities construed by migrant populations in late antiquity and Middle Ages.
} 
the rest of the community are in constant opposition. According to this, all European legal theories were founded on this ambivalence between 'individualistic theories of liberty and altruistic teachings about duty'. ${ }^{89}$ This perfectly relates to that tension between EU's welfarist aspirations and market liberal attitudes already discussed in the section (I).

European legal culture is also legalistic, i.e. characterised by a need to base all decisions about social conflicts and interactions on a general rule of law based on moral/social/ political values. The fundamental position occupied by this "principle of legality" is to be tracked back to the heavily professional and formal manners in which justice was administrated in ancient Rome. ${ }^{90}$ This 'jurisprudential formalism' turns into conceiving social duties and rights as 'objectified legal relationships, removed, in principle, from arbitrariness as well as from mercy'. ${ }^{11}$ Upon the conversion of elitist privileges into general freedoms and universal human rights for all, a tacit clash between individual and general postulates of justice was created..$^{22}$ This culture is claimed to be also intellectualist, meaning that it tends to grasp all legal phenomena by 'means of epistemological methods' which led European legal minds to approach law in terms of themes, concepts and coherence. ${ }^{93}$

While Wieacker identifies the prevailing common elements of legal thinking rooted in Europe's historical developments, what Hesselink describes is a new European legal culture which has been emerging due to the Europeanisation of private law. The typical aspect of such culture is the predominance of pragmatism over formalism: steaming from the CJEU's substance-oriented approach, there has been a shift away from dogmatism to a level where the Court interprets the law upon functional policy consideration rather than upon the form or the language of its provisions. ${ }^{94}$ With less formalism, the law is also less fixated, hence more easily adjustable to cultural diversities ${ }^{95}$ especially if we consider that most of the cultural incompatibilities relate to formal rules rather than substantive differences in legal concepts. ${ }^{6}$ Moreover, this EU culture is also interdisciplinary (i.e., it does

\footnotetext{
89 Wiaecker 1990, p. 20-22.

90 Wiaecker 1990, p. 23.

91 Wiaecker 1990, p. 24-25.

92 Ibid.

93 Wiaecker 1990, p. 25.

94 Hesselink 2002, p. 72-73.

95 Hesselink 2002, p. 77.

96 Hesselink 2002, p. 75.
} 
not respect the traditional separations between private and public law, between legal and social disciplines) and pluralistic (i.e., less focus on national codes and regulations and more on the involvement of other legal institutions and actors). 97

\subsection{Defending the European project}

While the real existence of such new European culture may still be debated, what cannot be denied is that legal cultures can change. Traditions can evolve..$^{98}$ For those claiming that cultural differences impair legal integration, it is still to be proven why cultures should be conceived as something 'impenetrable, rather than porous'.99 There is no scientific proof showing that values, traditions, interests cannot be modified, for all we know they are in constant evolution or, at least, parts of them change in relation to new social developments and interactions with other groups or new realities, while other elements remain a constant. ${ }^{100}$ It might just take some time to acknowledge these changes and accept or adjust to them.

Assuming pluralism in the cultures of Europe, the author also accepts pluralism in the law. Legal pluralism is here intended as a plurality of legislative authorities on one territory, in other words 'different equally valid claims to legal authority have come to exist', creating a scenario in which separate lawmakers give law on different parts of private law (as well as constitutional or criminal law). ${ }^{101}$ These lawgivers may sometime overlap or conflict with each other, and this subsequently implies that the coherence of the countries' legal orders does not lie with one single national institution, instead it lies in the efficient coordination of legislative initiative and implementation between national and supranational lawgivers.

Taking, for instance, the Regulation on a Common European Sales Law (CESL), the proposal is welcomed. A common set of rules in the field of contract law would be provided to the market citizens offering them the choice of stepping out their national regime to join a European community- hence a European legal culture: the idea makes a lot of sense. Considering what stated so far, we have a open market field on which citizens are offered the opportunity to trade cross-border, they are in need to having their basic rights and

\footnotetext{
97 Hesselink 2002, p. 73.

98 Zimmermann 1996, p. 585.

99 Cottorrell 2008, p, 28.

100 Zimmermann 1996, p. 585; Cottorrell 2008, p, 28.

101 Smits 2012, p. 3- 4 .
} 
interests protected, hence it seems quite logical to say that the law should match its speed with these social developments. The real problem with this specific instrument, however, is that it is too limited in its scope: the law of property and of tort are entirely excluded from it, yet many aspects on ownership, title, damage, unjust enrichment are immediately interconnected with contracts. It is not wise to create an instrument whose scope is so narrow that it cripples it. The whole purpose is that of reducing costs of crossborder transactions, but these reductions are not appealing enough. Under the proposal as it stands now, in fact, in the case of a Danish SME wishing to contract under CESL in The Netherlands, the Danish business might still need to get legal advice on Dutch property issues, hence it would still need to invest resources on legal counselling. Setting aside for a moment the difficulties related to practical feasibility and political wills, a more efficient strategy would be that of designing a system of patrimonial law in which all potential disputes related to a contract could find their solution in one single instrument. National private law systems have always been coherent and comprehensive, a European one should be no different.

Nonetheless, CESL, as any hypothetical EU patrimonial law regime, is to be defended as the manifestation of the citizens' liberty to choose another identity (the European identity), allowing them to opt into a common European model of justice between private parties. ${ }^{102}$ As the Internal Market is not a jungle, this law would provide rules for regulating the market arena by providing safety nets for its citizens ${ }^{103}$ and by striking a balance between party autonomy (necessary for the market to flourish) and fundamental rights (as embedded into the Charter of Fundamental Rights and other constitutional principles established by the CJEU). All in all, by allowing intercultural discourse and exchanges, by endorsing and accepting new traditions, by permitting external influences to impact national mentalities, we can foster the slow, yet necessary, creation of a common legal culture, a culture which could be capable of existing next to the national ones, a culture without which any meaningful legal integration cannot be achieved.

102 Hesselink 2012, p. 1 and p. 15.

103 Hesselink 2012, p. 15. 


\section{Education in the politics of legal change}

'The universal man is universally educated', said Professor Andreas Wirsching during the last Schumann Lecture held in Maastricht this year. ${ }^{104}$ On that evening the discussion began with an historical excursus on the Europe of forty years ago, a Europe stuck in the grip of communism and other totalitarianisms, where economic developments diverged greatly and it was not possible to move from one country to the other-certainly not for working nor studying aboard. When trade was liberalized and a single market designed, the impact of globalization on working patterns and methods became sticking. The question then was: is knowledge power? His answer was positive. In the post-industrial era, knowledge and technologies changed the working manners and, in turn, society. The Professor continued by discussing a series of strategies adopted by the EU in order to coop with the phenomenon of globalization, in particular he drew his attention to what is known as 'knowledge society' and its relation with education. By shifting the labour market from collective (e.g., trade unions) to individual responsibilities, a more autonomous and dynamic type of worker was created: it is the 'knowledge worker', the successor of the 'white collars'.

In his view, this worker survives to globalization only if universally educated. In our network society education moves in concomitance with economic development, hence we must create a system which is capable of producing flexible workers able to face information technologies and the speed with which these develop. Education becomes a mean through which EU globalization strategies are carried out. In other words, to make Europe more competitive, education systems should be improved. This approach towards education was also employed during the Lisbon European Council in March 2000. On that occasion, the Union set a 'new strategic goal' for the upcoming decade, namely that of becoming 'the most competitive and dynamic knowledge-based economy in the world capable of sustainable economic growth with more and better jobs and greater social cohesion' and in which '(e)very citizen must be equipped with the skills needed to live and work in this new information society'.105 The Council defined a series of necessary steps towards the formation of a European Area of Research and Innovation, calling for:

104 Wirsching 2013.

105 Lisbon European Council 23 and 24 March 2000: Conclusions of the Presidency, p. 2-3. 
- 'networking national and joint research programmes';

- improving 'the environment for private research investment';

- facilitating 'the creation by 2001 of a very high-speed transeuropean network of electronic scientific communications, [...] linking research institutions and universities, as well as scientific libraries, scientific centres and, progressively, schools';

- increasing 'the mobility of researchers in Europe by 2002 [...] to attract and retain high-quality research talent in Europe'.106

During March 2002, the Barcelona European Council even prescribed a 3\% of GDP to be devolved to Research and Development by 2010 with the aim of making Europe more competitive on the global markets. ${ }^{107}$

Now, whether all these goals were actually achieved is highly debatable, but what is interesting for the purposes of this paper is the prevailing economic functionalism taken towards education, an approach also questioned by the Professor during the Schumann Lecture. It is certainly logic for the Union's Institutions to incentivize research and innovation in the context of economic competition, however the author would prefer to focus on the students and researchers not so much in terms of 'market individuals' or 'hominis economicis' 108 but rather as the 'human foundations'109 of Europe. Amongst them there are the human foundations of legal research (both in the field of constitutional and private law scholarships), and, consequently, the driving forces of the legal integration process. From this stems the claim that it is through education that we may channel the harmonization project. ${ }^{10}$

For this reason, after having assessed the legitimate necessity of further harmonization in private law and the transnational network of political actors involved in the integration project (section I), and after having rebutted the cultural arguments often advanced by nationalist forces against this normative necessity (section II), the analysis now turns its attention towards the legal education currently offered to the transnational network and terminates with the proposal for a better educational system.

106 Lisbon European Council 2000, p. 4.

107 Barcelona European Council 15 and 16 March 2002: Conclusions of the Presidency, p. 20.

108 Two terms employed by Wirsching during the Schumann Lecture.

109 von Bogdandy 2009, p. 364-400, p. 390.

110 Mattei \& Nicola 2006, p. 1-63, p. 7; Vauchez 2013, p. 1-3. 


\subsection{The national education systems in the European context}

As of today, legal science in Europe has been mainly national in substance, methodology and approach."1" This is evident in the courses offered- predominantly on national law and only to a minor extent on international and comparative law, in the examination requirements, in the themes dealt by the literature, in the conditions for the appointment of law teachersworrisome in terms of their mobility, in the criteria with which lawyers and judges gain access to the bar. ${ }^{12}$ The author does not sustain that these national curricula and criteria should disappear, in fact we will continue to need nationally trained lawyers willing to work on national cases within the States' territorial boundaries. However, what is denounced here is that, with same nationalist approach discussed in the previous section, domestic bars and professors are still neglecting the impact of EU law on their national systems and see no reason for leaving more space to EU-related subjects. ${ }^{13}$ The domestic lawyers who spent many years studying national codes (thinking that was the only acceptable law) have a lot of difficulty in accepting the idea that other legal orders could receive equal consideration. Conservative, focused on their own personal interests, proud of the efforts put into studying the letter of the law and afraid of a legal field they do not master, national practitioners and professors hold tight to domestic subjects and outlooks.

These national education systems are highly dogmatic and positivistic in their approach, even orthodox sometimes. Students are taught the law as it stands in that specific place at that specific time, an approach that assumes the law to be fixed in a system of private law, hence in the structure of its codes, ground principles and distinctions. Even the caselaw, if taught at all, is presented as an abstract rule (massima) to be correctly placed within the system, whereas the facts of the case are almost completely left aside. ${ }^{114}$ This gives the impression that law is not problematic, while in reality, those who practice it everyday know that '(I)aw is context, battle, and manifold'.15 The textbook generally resembles a commentary of the national civil code and for each exam question a "key answer" is provided, as if also in reality there was a single correct answer. This method of abstract standardisation generates the illusion that law is always rational and coherent. ${ }^{16}$

\footnotetext{
111 Zimmermann 1996, p.3.

112 Zimmermann 1996, p. 3.

113 Heringa 2011, p. 7-10.

114 Hesselink 2001, p. 17-18; Somek 2009, p. 424-441, p. 426-427.

115 Hesselink 2001, p. 18, footnote 37 .

116 Hesselink 2001, p. 19
} 
Without intending to dig any further into how national law is taught in national universities, the first observation is that the positivistic approach of national curricula may have proven efficient for the past century in a system where only national law mattered. Therefore, in so far these universities decide to maintain a strictly domestic point of view on the law, this methodology may very well be preserved. However, this author sustains that the moment schools decide to insert international or EU-related topics into their curricula, this dogmatic approach cannot be equally applied. Before elaborating on the specific features that a truly EU scholarship should possess, it is worth mentioning why law schools should accept the relevance of comparative and European studies in the first place.

\subsection{The still missing European law graduates}

A child born in Manchester is not a natural solicitor as much as an Italian child is not a civilista (i.e., the Italian denomination of a private law lawyer). In other words, it is all about the type of education that we are offered: the legal way of thinking is, as a matter of fact, simply the final result of the legal education received. ${ }^{17}$ If the English solicitor and the Italian civilista think the way they do (and think differently) is purely because they studied and trained their minds one in the English common law university and the other in the Italian civil law school. Furthermore, most of the academics and practitioners already involved on a European scale will agree with the assertion that, due to the creation of global markets, legal issues became more and more transnational, demanding lawyers capable of thinking across jurisdictional borders. ${ }^{.18}$ Therefore, by assuming that lawyers think as they were taught to think ${ }^{119}$, it can be safely sustained that in order to boost the European legal labour market it is necessary to re-think the structure of law curricula. As previously demonstrated in reference to the field of private law, the impact of the Union's legislation on national orders is undeniable and yet national education systems seem to have stayed a step behind. ${ }^{120}$

By shaping a law scholarship that is authentically European, we can create graduates that are no longer constrained to one single national order and that know how to operate in an international legal environment- we form lawyers capable of thinking in a truly European manner. This requires the denationalization of domestic education systems, a process

117 de Witte 2013, p. 107; S. van Erp 2011, p. 79.

118 See, inter alia, Heringa \& Akkermans 2011; Vauchez \& de Witte 2013; Faure et al. 2002.

119 van Erp 2011, p. 79

120 Akkermans 2011, p. 159; Kornet 2011. 
which, unfortunately, has remained rather limited. Looking back at concepts of proximity and multiculturalism (as described in sections I and II): these can only be acknowledged and accepted if the new generations are informed about them. This poses fundamental questions to the traditional law curricula because, as already previously described, these tend to be introspective and rejecting of external dimensions.

Even if the belief is that any legal practitioner should receive a sufficient amount of EUrelated knowledge, the main interest of this analysis is based not so much on those individuals practicing on a national level, rather on the level and quality of knowledge that the transnational network is offered. Here the author refers to legal consultants or agents of governments and institutions, academics involved in schools, legal writings, speeches at conferences, clerks, judges, national and international practitioners: whether they like it or not, they are all characters of the same story. Organized in networks, they cannot be regarded as isolated players: as any other social actor, they are members of a dense web of relations and bonds within and across national boundaries ${ }^{121}$ from this, the notion 'transnational network'. For this reason, the author does not preoccupy so much with the improvement of the EU-related teachings in national schools (certainly necessary!), rather with the creation of innovative EU law schools independent from national faculties and capable of providing the transnational network with the best education and training possible.

\subsection{National law curricula gone European}

Even if most of the lawyers are still trained on national basis, we cannot deny that many schools have included (or at least have tried to) EU and comparative law courses, albeit in some countries more than others. ${ }^{122}$ The problems with these curricula, however, are that their courses i) maintain a "national aftertaste", which in turns does nothing but fragmenting the EU scholarship, and ii) are placed at the end of the curricula (i.e., once the legal mind of the student is already too socked with national doctrines to be able to embrace foreign legal orders).

Starting from the latter point ii), it has been proven that to teach comparative and/or international laws after having taught the national legal order (sequential approach) is not exactly the best way of intruding students to foreign legal sources. The great majority

121 Vauchez 2013, p. 3-5.

122 Heringa 2011, p. 10. 
of traditional law schools tends to firstly introduce the students to their own national law and only after they have obtained deep knowledge of such law, the students are confronted with comparative courses. The problem with this sequential approach is that, by the time the students face the foreign systems, their legal minds are already set on the domestic one. From that point in time, whatever other system or legal approach the students will encounter, they will perceive it as "abnormal", as an anomaly. ${ }^{123}$ An integrative approach which incorporates comparative analyses at the very beginning of the curricula is to be preferred- this point will be elaborate further below.

With respect to point $i$ ), the argument is that whenever a national school decides to engage in EU law teachings, their courses maintain a "national taste": EU law is presented as contextualized and transformed by the domestic legal order in which is it articulated. ${ }^{124}$ Hence, it is no longer the law of the European Union, but the "28 ways" of interpreting and teaching such law. In a way, it is as if in each Member State the EU law taught was an hybrid form between EU legislation and national legal mentalities. These national ways of teaching EU law have caused the fragmentation of its scholarship. Since it is placed in the national 'legal universe' and because it is taught by professors whose studies were national, the themes of EU law which they explore (and teach), the academic styles they employ, the textbooks they propose: these are all dictated by their national educational backgrounds. ${ }^{125}$ By way of example, looking at frequently prescribed textbook of Craig and de Búrca's EU Law- Text Cases and Materials ${ }^{126}$, on an average, out of 600 of its external references, only 3 are written in a language other than English. This means that roughly 597 sources were focused on a scholarship produced within the UK and thus with an English approach to the subject. ${ }^{127}$ The same holds true for any other material on EU law: the nationality of the sources used is most likely to be the same of the language employed. ${ }^{128}$

An equal reasoning is valid for the production of legal writings: as diffusion of EU law takes place in different languages and via separate publication channels, this translates in a lack of interaction between them. On the Italian EU law journal, Diritto dell'Unione Europea,

\footnotetext{
123 Smits 2011 p. 11-13; Husa 2009, p. 913-926.

124 Vauchez 2013, p. 14; de Witte 2013, p. 106.

125 De Witte 2013, p. 106-108.

126 Craig \& de Búrca 2011.

127 De Witte 2013, p. 108.

128 lbid.
} 
between 2005 and 2006 out of 74 total publications only 10 were submitted by authors not established in Italy. During the same years, on the German journal Europarecht, out of 80 only 2 contributions were from foreign-based authors. ${ }^{22}$ Yet these are both European journals. Together with other factors, such as i) students studying EU law in a country other than the one in which they received their previous education, ii) Erasmus programs, iii) lack of mobility of professors and lecturers (due to bureaucratic burdens), ${ }^{130}$ this contributes to the fragmentation and inconsistency of the EU scholarship.

Having assessed these elements, this author sustains that the best way of spreading an accurate and coherent knowledge on the law of the Union would be that of creating a EU law scholarship as detached as possible from national education systems. This scholarship should be based on a disciplinary identity that is no longer dependent on whether the norms that are being studied flow from sources of national, international or European authorities. In other words, it should lie on a flexible and pluralistic academic identity. ${ }^{131}$

\subsection{Comparative and EU studies: how and why}

In order to increase the denationalization of legal studies, one of the most powerful teaching tool would be the comparative method. By employing this methodology, the students are exposed to different and unfamiliar ways of approaching the law, different mentalities. The added value is not found into the mere learning of foreign substantial rules- that would simply amount to an empty comparative exercise carried out for the sake of increasing pure knowledge on other legal orders. The real quality of a meaningful comparative course is that it allows the student to get acquainted with different ways of logical thinking, different approaches towards the legal issues, different legal mentalities. It exposes the student to the idea that there can be different ways of solving common problems, several ways of perceiving and achieving justice and that more than one way may be valid or efficient. By comparing we also incentivize the formation of "humble legal minds", intended as minds which do not necessarily perceive their domestic law as the only law, rather they are willing to give equal consideration to foreign systems, allowing for a dialogue and exchange with the otherness. ${ }^{132}$

129 De Witte 2013, p. 111-113; de Witte 2011, p. 34-37.

130 De Witte 2013, p. 110-111.

131 von Bogdandy 2012, p. 614-626, p. 625-626.

132 Smits 2011, p. 2. 
It is precisely through this exchange with the otherness that cultures may embrace external elements and that multifaceted academic and professional identities are shaped. As already mentioned above, the most efficient way of exposing students to foreign and international laws is by introducing comparative courses at the very beginning of their curricula. ${ }^{133}$ In this way, their minds are not definitively set on one specific system, hence open enough to accept the foreign without any prejudice. By working with comparative materials in which texts from several jurisdictions are presented, students are forced to evaluate each approach/solution and 'construct their own understanding of what is right or wrong'. ${ }^{34}$ The reason why a comparative (and European for that matter) course is valuable is because the law is no longer a national phenomenon, instead it flows from a plurality of national and international sources hence it can no longer be regarded as tied to one single nation-state. ${ }^{135}$ By accepting legal pluralism and rejecting the nationalistic approach towards law, ${ }^{136}$ the necessity of introducing this sort of courses becomes obvious.

Furthermore, it is only through the comparison that future practitioners can realize that the differences between the substantial rules are, after all, not insurmountable: they may discover that divergences are not so fundamental, and that perhaps legal systems are more alike than firstly perceived, especially in terms of underlying policy considerations, principles, values and ground rules. ${ }^{137}$ And even if differences are there, these can be overcome by general interests in social and economic integration. ${ }^{1{ }^{8}} \mathrm{All}$ in all, considering that it is the legal practitioners and not the legislature to determine the authority of a source, schools should not simply sit back and passively hand down to the students the statutory laws and the case-law, rather they should actively react with the intent of forging international and pluralistic minds capable of 'shaping the future of the law'.139

Of equal importance are courses on the law of the European Union. As for the materials with which this could be studied, some worry that there is simply not enough substantive EU law to make a proper course out of it. On the contrary, by using legislative projects such

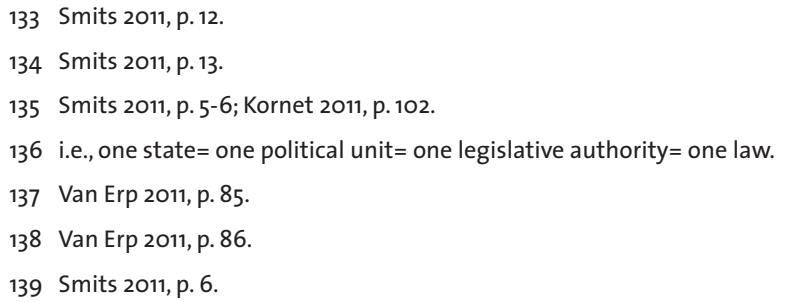


as the Principles of European Law (PEL), the Acquis Principles (ACQP), the Draft Common Frame of Reference (DCFR), the Common European Sales Law (CESL) and the extensive caselaw of the CJEU, we would have sufficient texts from which beginning to build a course. Codification projects such as the DCFR are 'excellent teaching tools' because they enshrine comparative notes from national systems as well as general principles of EU law. ${ }^{140}$ The same holds true for the case-law: very often the judgements constitute a rich source for academic and educational materials due to their policy-oriented and pragmatic approach in which national measures and actions are compared and revised upon European ground rules. ${ }^{141}$ With regards to the language, this author believes that it is possible to construct the course almost exclusively in English as this is the Union's lingua franca. ${ }^{142}$ Many would argue that the law should be studied in the language in which it is written, but precisely because the Union's law is not national law then it is legitimate to teach it by using the English language. Moreover, if academics and students are required to write and study in English, this could foster the exchange of information and staff from one university to the other, hence facilitate the divulgation of knowledge in the field of EU law. ${ }^{143}$

By working towards a uniform education system, in which materials are written in the same language, in which teaching methods and staff members are exchanged, in which graduates appreciate the advantages of 'seeking inspiration from foreign colleagues' 144 , a common legal discourse without language nor territorial boundaries may be generated. This, in turn, will foster further improvements in education: more numerous and more accurate teaching materials would be made available from the cooperation of professors and researchers while the EU scholarship would avoid any fragmentation. The envisaged final result is that of a transnational network much better educated, capable of pushing legal integration in the right direction.

\subsection{Outside the comfort zone: a truly European scholarship}

Based on the analysis carried throughout the whole paper, this author encourages the academic community to gain awareness on the urge of building a new scholarship, capable of preparing the future generations for the challenges posed against (and by)

\footnotetext{
140 Akkermans 2009, p. 803-813, p. 807-809 and 812 .

141 lbid.

142 A. Heringa 2011, p. 5-6.

143 Akkermans 2009, p. 813 .

144 Lopez-Rodriguez 2004, p. 1220.
} 
the European project. This school should begin with a three years of bachelor studies and continue with another two years of master specializations.

During the first year, students would study general themes on EU institutional, market and constitutional law combined with a course on the legal history of Europe. This should equip them with the necessary basic understandings of the Union's functioning and with the common historical basement on with the Union was erected. ${ }^{145}$ For the subsequent two years at the bachelor level, the students should decide whether to pursue the private or the public law track, and based on their choice, they would only follow courses in that area of law. During these two years, they would follow comparative courses but also courses on pure EU law. Attention should be given to the case-law of the CJEU and to materials written in different countries. The class should move from a general topic or issue and build the student's knowledge based on the solutions offered in the several jurisdictions as well as those adopted by the Union in previous legislative acts or projects. ${ }^{146}$ Courses should start from ground principles and doctrines and then move onto the specific substantial rules. ${ }^{147}$ On top of this, the school would offer a course on the political affairs of the Union and skills courses on legal writing and researching. Finally, interdisciplinary projects should be supported.

After these three years at the bachelor level, the graduates should have gained a sufficient understanding of how EU law is created and applied, they should be aware of the legal and political dynamics happening within the Union's Institutions. Furthermore, they should possess considerable skills in terms of comparative legal thinking and should feel quite confident in practicing the law on an international plane, able to adapt to different law instruments and different legal environments. The most valuable tool given to these graduates would not be that of knowing any given law, rather that of knowing how to approach different systems without feeling lost in them- as the key to legal practice is not knowing the answer, but knowing how to find the answer. Following the bachelor degree, the two years would be devoted to the specialization in one national system of the Union. Through this, the student would be able to deepen his or her knowledge on one specific Member State's legal order, on its technicalities and substantial laws. Instead of first learning about their own domestic system and then take a couple of courses on

145 On this matter, see: Zimmermann 1996.

146 Smits 2011; Akkermans 2009.

147 lbid. 
comparative or EU law (i.e., the current structure of law schools in Europe), the student would begin with comparative and European courses and, only after, he or she would move on to more detailed national studies.

All courses during the first three years would be given in English, while at the master level the course could be taught in the national language of the legal system chosen. The pragmatic and practical approach should be maintained throughout the whole five years. As described in the previous sections, politics and cultures can be perceived as organized in networks, hence this EU law school should be constructed accordingly: by creating a web of faculties all over Europe, staff members, researchers and students could be exchanged, especially at the bachelor level where courses would be similar and the language the same for all. Even at the master level, visiting other faculties could be an option, particularly for the researchers and the students. Materials and teaching tools should be exchanged amongst the faculties, this should allow the improvement of the school and, eventually, it may even inspire and spill-over onto the national universities: the more successful and competitive this school turns out to be, the more domestic schools would be incentivized to rejuvenate their traditional curricula.

\section{Conclusion}

In the attempt of reacting to the often criticised market integration, in which normative national differences are accused of obstructing social coherence, this paper aimed at analyzing the political and cultural realities currently existing within the European Union. In order to foster legal proximity between the Member States and boost the development of a system of private law for Europe, an innovative EU law curriculum should be supported. On the political side, EU private law is necessary to create an order in which market citizens may move cross-border while always having a legal system which protects their constitutional and fundamental rights, regardless of whether they are carrying out their economic activities within or outside their native country. In view of its supranational constitutional character, private law is vested with the role of ensuring social protection within the economic community. Through a properly educated and well-informed deliberative discourse, the political actors may incentivize private law instruments capable of completing the lacunas present in the nation-state models. These lacunas stem for the legitimate incapacity of national constitutions to acknowledge foreign individuals inside their societies. In other words, the first step was in the creation of an Economic 
Constitution, now it is time to add the social component to it and an EU private law system would precisely aim at doing so.

Very often, especially in times of strong scepticism against the Union's action, nationalist movements tend to oppose legal harmonization based on cultural arguments. By perceiving private law as the expression of a country's legal identity, they claim private law should remain national. However, after having demonstrated that cultures are heterogeneous and pluralistic rather than unitary and confined into national boundaries, this author sustains that it is legitimate to defend a legislative project in which European values and principles are enshrined. As persons with international backgrounds exist, it is legitimate to provide them with a European legal order in which they may recognize and protect their rights on an transnational scale.

The key to a more coherent and efficient legislative action lies in the ability of providing a suitable legal scholarship to the persons responsible for the shaping of EU law and its future development. The focus is on the transnational network of legal practitioners and academics, which operates in Europe and whose activity has the potential of influencing institutional and juridical rationales and decisions. The paper concludes with the proposal for a new European Law School, a school as detached as possible from the traditional domestic curricula. There professors, students and researchers would be working with interdisciplinary comparative and international materials, through which cultural and legal identities would be shaped without any prior national predisposition. Only by forming a truly European transnational network, capable of cooping with global markets and cross-border legal issues, it will possible to steer legal integration in the right direction. 


\section{Bibliography}

\section{Primary Sources:}

Case law:

- Case C-277/05, Société thermale d'Eugénie les Bains v Ministre de l'économie, des Finances et de l'Industrie [2007] ECR I-06415 (CJEU).

- Case C-412/06, Annelore Hamilton v Volksbank Filder [2008] ECR I-2383 (CJEU).

- Case C-489/07, Messner v Firma Stefan Krüger [2009] ECR I-7315 (CJEU).

European Council's documents:

- Barcelona European Council 15 and 16 March 2002: Conclusions of the Presidency.

- Lisbon European Council 23 and 24 March 2000: Conclusions of the Presidency.

\section{Secondary Sources:}

\section{Akkermans 2009}

- Bram Akkermans, 'Challenges in Legal Education and the Development of a New European Private Law', 10 German Law Journal 7 (2009), p. 803-813, p. 807-809 and 812.

\section{Akkermans 2011}

- Bram Akkermans, 'The Developments of European Private Law and Its Challenges on the Law School Curriculum', in: Aalt W. Heringa \& Bram Akkermans (Eds.), Educating European Lawyers, Intersentia: Antwerp (2011).

\section{Amato 2008}

- Giuliano Amato, 'Multilevel Europe and Private Law', in Making European Private Law- Governance Design, F. Cafaggi and H. Muir-Watt (Eds.), Edward Elgar Publishing Limited: Cheltenham (2008).

\section{Barnes 1966}

- J. A. Barnes, ‘Durkheim's Division of Labour in Society', 1 Man New Series 2 (1966), p. 158-175.

\section{Bierbrauer 1994}

- Günter Bierbrauer, 'Towards an Understanding of Legal Culture: Variations in Individualism and Collectivism Between Kurds, Lebanese, and Germans', 28 Law and Society Review 2 (1994), p. 243-264.

\section{Caruso 1997}

- Daniela Caruso, 'The Missing View of the Cathedral: The Private Law Paradigm of European Legal Integration', 3 European Law Journal 1 (1997), p. 3-32. 


\section{Comparato 2012}

- Guido Comparato, 'The Long Shadow of the Wolksgeist or: The Nationalist Dimension in European Private Law Discourse', 3 European Review of Contract Law (2012), p. 245- 259.

\section{Collins 1995}

- Hugh Collins, 'European Private Law and the Cultural Identity of States', 3 European Review of Private Law (1995), p. 353-365.

Cotterrell 2008

- Roger Cotterrell, 'Law and Culture- Inside and Beyond the Nation State', 31 Retfærd: Nordisk Juridisk Tidsskrift 123 (2008), p. 23-36.

\section{Cotterrell 2003}

- Roger Cotterrell, 'Comparatists and Sociology', in: Pierre Lagrand \& Roderick Munday (Eds.), Comparative Legal Studies: Traditions and Transitions, Cambridge University Press: Cambridge (2003).

De Witte 2011

- B. de Witte, 'European Union Law: A Common Core or a Fragmented Academic Discipline?', in: Aalt W. Heringa \& Bram Akkermans (Eds.), Educating European Lawyers, Intersentia: Antwerp (2011).

De Witte 2013

- Bruno de Witte, 'European Union Law: A Unified Academic Discipline?', in: Antoine Vauchez \& Bruno de Witte, Lawyering Europe- European Law as a Transnational Social Field, Hart Publishing: Oxford (2013).

Faure 2002

- Michael Faure, Jan Smits \& Hildegard Schneider (Eds.), Towards a European Ius Commune in Legal Education and Research, Intersentia: Antwerp (2002).

\section{Gibson \& Caldeira 1996}

- James L. Gibson \& Gregory A. Caldeira, 'The Legal Cultures of Europe', 30 Law and Society Review 1 (1996).

\section{Glenn 2004}

- Patrick Glenn, Legal Traditions of the World: Sustainable Diversity in Law, $2^{\text {nd }}$ ed. Oxford University Press: Oxford (2004).

\section{Gellner 2006}

- Ernest Gellner, Nations and Nationalism, $2^{\text {nd }}$ ed. Blackwell Publishing: Oxford (2006).

Heringa 2011

- Aalt W. Heringa, 'Towards a Truly European Legal Education', in: Educating European Lawyers, Intersentia: Antwerp (2011). 


\section{Heringa \& Akkermans 2011}

- Aalt W. Heringa \& Bram Akkermans (Eds.), Educating European Lawyers, Intersentia: Antwerp (2011).

Hesselink 2002

- Martijn W. Hesselink, The New European Legal Culture: Essay on the Future of Private Law in Europe, Kluwer Law International: Deventer (2002).

Hesselink 2012

- Martjin W. Hesselink, 'The Case for a Common European Sales Law in an Age of Rising Nationalism', Centre for the Study of the European Contract Law Working Paper Series No. 2012-01 (2012).

\section{Husa 2009}

- J. Husa,'Turning the Curriculum Upside Down: Comparative Law as an Educational Tool for Constructing the Pluralistic Legal Mind', 10 German Law Journal (2009), p. 913-926.

\section{Husa 2012}

- Jaakko Husa, 'Legal Cultures vs. Legal Traditions- Different Epistemologies?', Maastricht European Private Law Institute (M-EPLI) Working Paper No. 2012/18 (2012).

\section{Joerges 1997}

- Christian Joerges, 'The Impact of European Legal Integration on Private Law: Reductionist Perceptions, True Conflicts and New Constitutional Perspective', 3 European Law Journal 4 (1997), p. 378-406.

Joerges \& Neyer 2006

- Christian Joerges \& Jürgen Neyer, '"Deliberative Supranationalism" Revisited', EUI Working Paper LAW No.2006/20 (2006).

\section{Kornet 2011}

- Nicole Kornet, 'Building a European-oriented Law Curriculum', in: Aalt W. Heringa \& Bram Akkermans (Eds.), Educating European Lawyers, Intersentia: Antwerp (2011).

Lando 1997

- Ole Lando, 'Why Codify the European Private Law of Contract?', 5 European Review of Private Law 4 (1997), p. 525-536.

\section{Legrand 1997}

- Pierre Legrand, 'Against a European Civil Code', 6o The Modern Law Review 1 (1997), p. 44-63.

Lopez-Rodriguez 2004

- Ana M. Lopez-Rodriguez,'Towards a European Civil Code Without a Common European Legal Culture? The Link Between Law, Language and Culture', 29 Brooklyn Journal of International Law., (2003-2004), p. 1195- 1220. 


\section{Lurger 2011}

- Brigitta Lurger, 'The "Social" Side of Contract Law and the New Principle of Regard and Fairness', in Towards a European Civil Code, A. S. Hartkamp et al. (Eds.), Kluwer Law International: Bedfordshire (2011), p. 364-365.

\section{Mak 2012}

- Chantal Mak, 'Europe-Building through Private law. Lessons from Constitutional Theory', Centre for the Study of European Contract Law- Working Paper Series No. 2012-02 (2012).

\section{Mattei \& Nicola 2006}

- Ugo Mattei \& Fernanda Nicola,'A “Social Dimension” in European Private Law? The Call for Setting a Progressive Agenda', 41 New England Law Review 1 (2006), p. 1-63.

\section{Micklitz 2010}

- Hans-W. Micklitz, 'Failures of Ideological Preconceptions? Thoughts on Two Grand Projects: The European Constitution and the European Civil Code', in The Many Constitutions of Europe, K. Tuori and S. Sankari (Eds.), Ashgate Publishing Limited (2010), Farnham, p. 109-140.

\section{Münch 2008}

- Richard Münch, 'Constructing a European Society by Jurisdiction', 14 European Law Journal 5 (2008), p. 519.541.

\section{Reich 2011}

- Nobel Reich, 'The Social, Political and Cultural Dimension of EU Private Law', in European Private Law-Current Status and Perspectives, R. Schulze \& H. Schulte-Nölke (Eds.), Sellier European Law Publishers: Munich (2011).

\section{Sandel 1982}

- M. Sandel, Liberalism and the Limits of Justice, Cambridge University Press: Cambridge (1982).

\section{Simpson 1947}

- Durkheim's Division of Labour in Society, G. Simpson The Free Press (1947).

Smits 2011

- Jan M. Smits, 'European Legal Education, or: How to Prepare Students for Global Citizenship?', Maastricht European Private Law Institute, Working Paper No. 2011/O2, (2011).

Smits 2012

- Jan M. Smits, 'A Radical View of Legal Pluralism', Maastricht European Private Law Institute (M.-EPLI) Working Papers No. 2012/1 (2012).

\section{Somek 2009}

- Alexander Somek,'The Indelible Science of Law', 7 International Journal of Constitutional Law 3 (2009), p. 424-441. 
Study Group on Social Justice in European Private Law 2004

- Study Group on Social Justice in European Private Law, 'Social Justice in European Contract Law: a Manifesto', 10 European Law Journal 6 (2004), p. 653-674.

Van Erp 2011

- Sjef van Erp, 'Teaching Law in Europe: From an Intra-Systemic, via a Trans-systemic to a Supra-systemic Approach', in: Aalt W. Heringa \& Bram Akkermans (Eds.), Educating European Lawyers, Intersentia: Antwerp (2011).

Van Gerven 2001

- Walter van Gerven, 'Codifying European Private Law', text of the Jean Monnet lecture given at Groningen University on 13 September 2001.

Van Gerven \& Lierman 2003

- W. van Gerven \& S. Lierman's contribution in: J. H. H. Weiler \& M. Wind (Eds.), European Constitutionalism Beyond the State, Cambridge University Press: Cambridge (2003).

Varga 2005

- Csaba Varga, 'Legal Traditions? In Search for Families and Cultures of Law', 46 Acta Juridica Hungarica, (2005), p. 177-197.

Vauchez 2013

- Antoine Vauchez, 'Introduction. Euro-lawyering, Transnational Social Fields and European Polity-Building', in: Antoine Vauchez \& Bruno de Witte, Lawyering EuropeEuropean Law as a Transnational Social Field, Hart Publishing: Oxford (2013).

Vauchez \& de Witte 2013

- Antoine Vauchez \& Bruno de Witte, Lawyering Europe-European Law as a Transnational Social Field, Hart Publishing: Oxford (2013).

Von Bogdandy 2009

- Armin von Bogdandy, 'The Past and Promise of Doctrinal Constructivism: A Strategy for Responding to the Challenges Facing Constitutional Scholarship in Europe', 7 International Journal of Constitutional Law 3 (2009),p. 364-400.

Von Bogdandy 2012

- Armin von Bogdandy, 'National Legal Scholarship in the European Legal Arena- A Manifesto', 10 International Journal of Constitutional Law 3 (2012), p. 614-626.

\section{Wacks 2006}

- Raymond Wacks, The Philosophy of Law- A Very Short Introduction, Oxford University Press: New York (2006).

\section{Wieacker 1990}

- Franz Wieacker, 'Foundations of European Legal Culture', 38 The American Journal of Comparative Law 1 (1990), p. 1-29. 
Zimmermann 2009

- Reinhard Zimmermann, 'The Present State of European Private Law', 57 The American Journal of Comparative Law 2 (2009), p. 479-512.

Zimmermann 1996

- Reinhard Zimmermann, 'Savigny's Legacy: Legal History, Comparative Law, and the Emergence of a European Legal Science', 112 Law Quarterly Review (1996), p.576-605.

\section{Internet sources:}

- The Chronicle of University of Michigan (29 March 1869) (last visited on 12 July 2013).

- Andreas Wirsching, 'European Strategies for Globalization since 1980', Schumann Lecture o6 May 2013, its video available at:

http://www.youtube.com/watch?v=JeT6Erz/THs (last visited on o3 May 2013). 